\title{
The Death of Steve Irwin and Its Controversy
}

\author{
Arif Rohman \\ School of Humanities and Social Sciences \\ Charles Sturt University
}

Steve Irwin occupied a special place in the Australian psyche which was shown by the extraordinary reaction to his death. Those who admired Irwin as a hero called him a wildlife warrior because of his skills and bravery in taking care of many animals, especially crocodiles. He also made a good impression as a celebrity and conservationist with his masculinity, enthusiasm and spirit to promote the wild animals' conservation. Like any romantic story, Irwin died as a hero doing what 'he loved and fought for' (Himes, 2006). On the contrary, there are other who claimed that Steve Irwin went to far by invading the animal realm. This essay will discuss both the positive and negative responses to the Steve Irwin's death, and try to identify the reasons behind this debate.

In her article, Greer (2006) stated that Irwin's death was basically the revenge of the animal kingdom. She argued that animals also need space to live in their natural habitat, but Irwin broke and ignored this conservation ethic and created a new genre of animal documentary film for entertainment purposes which was 'nature nasty'. On the subject of conservation, it is a consensus that protection of the habitat of wild creatures is an essential part of this process. Greer was more disappointed in Irwin when in 2004 he fed a crocodile with a dead chicken in one hand and his baby in the other hand. Although a disaster did not happen, Greer said that using a baby as part of the show was dangerous and was a silly thing and she called it child abuse.

However, Irwin tried to defend himself from the critics by saying that the crocodile was under his control and he was sure that disaster would not happen. In Greer's opinion, there was nobody who could completely guarantee control of wild animals such as crocodiles. In this context, Greer said that Irwin was overly confident in his approaches, saying that, 'That sort of self-delusion is what it takes to be a "real Aussie larrikin"'. According to Meredith Peach, a marine biologist, the possibility of a stingray attacking Irwin was only likely if it was provoked or felt threatened which also was a factor that influenced Greer to question and criticise what Irwin did.

Similarly, Hamilton (2006) criticises Irwin for his treatment of wild animals during his life. He compared him to David Attenborough, an animal expert who approaches creatures with an attitude of respect. Attenborough also keeps his distance when he meets 
animals, deadly or otherwise. Hamilton also says that Irwin did not respect wildlife and treated them as a 'spectacle for public amusement'. Greer and Hamilton became more unsympathetic to Irwin when he was shown illegally encroaching penguins, seals and humpback whales in Antarctica.

Although there were critics of Steve Irwin, some people still admired and called him a hero1 because they saw Irwin as a person who loved and dedicated all his life to wildlife conservation in Australia. He was a fabulous monster2 who worked hard for his dreams. So, it could be understood when the public mourned and reacted strongly against Greer because Irwin was their hero. The author, John Birmingham, went into a frenzy of abuse against Greer, revering Irwin's death with that of John F. Kennedy and Princess Diana (Geller, 2006; Hamilton, 2006).

The death of Steve Irwin in September 2006 had opened the discussion about heroism and national identity. It was shown by both the Australian and international media which instantly acknowledged him as a hero owing to his courage and his contribution to supporting wildlife conservation. Tumarkin, (2007: 13) argued that this euphoria was influenced by what Irwin did, as she said, 'Steve Irwin was passionate about the environment and despite his fame and wealth, he continued campaigning for conservationism'. She stated that Irwin's identity as a famous Australian celebrity3 and conservationist who tried to do the best for his country.

Lee (2006: 15), described Irwin's strong commitment to animals, as Irwin himself, once said to the media, 'I have no fear of losing my life, if I have to save a koala or a crocodile or a kangaroo or a snake, mate, I will save it'. Frances Gray also mentioned Irwin's commitment, dedication and sacrifice to saving wildlife in Australia. She added that what he did was to realise his dreams to support animal conservation, saying, 'He raised money for conservation purposes, established a hospital for injured wildlife, even buying up land that could harbour wildlife population' (Gray, 2007: 102).

1 The term of hero refers to protagonist, star, and idol (Collins Thesaurus, 2006: 398). 2 A fabulous monster can be defined as 'a creature whose very existence is on show, whether as a moral lesson or an admirable model' (Buchbinder, 1998: 2-3).

3 Daniel Boorstin (in Turner, 2004: 5) defined a celebrity as 'a person who is well known for their well knowness' and 'fabricated on purpose to satisfy our exaggerated expectations of human greatness'. 
As a celebrity, Irwin embodied a mythology of masculinity4 for many working class people in Australia with the true blue, patriotic image (Gibson, 2007). He lived simple and wore khakis and hiking boots and was not affected by his popularity (Rayner, 2007). In his TV series, a movie and many shows, Irwin educated his audiences about real wild animals. Irwin also helped to attract tourists to Australia and in February 2006, he received an award for his contribution from Tourism Australia (Williams, 2006).

Like other entertainers, environmentalist or not, Irwin needed audiences for his shows. In other words, people contributed and legitimased what Irwin did and his heroics by applauding, gasping and approving. They gave permission to Irwin to use animals for entertainment, to use his baby as the part of his attractions. His behaviour was also 'sanctioned by our unconscious desires to court death and win' (Gray, 2007: 101).

In conclusion, the responses and comments surrounding the death of Steve Irwin vary and the debate will still continue in the media and academic circles, portraying the different perspectives of wildlife conservation, Steve Irwin's heroism and his celebrity status. The public cannot deny that Steve Irwin obviously loved animals and his shows certainly showed how dangerous crocodiles are, so being careless in 'crocodile country' is likely to be deadly since many people have been killed or very badly injured when camping beside water courses or swimming in crocodile habitats in northern Australia.

\section{Bibliography:}

Buchbinder, D. 1998, Performance Anxieties: Re-producing Masculinity, Allen \& Unwin, St Leonards.

Code, L. 2000, Encyclopedia of Feminist Theories, Routledge, London.

Geller, A. 2006, 'What a crock! Croc critic slammed', New York Post, 9 Aug. Retrieved 20 Aug. 2008 from http://www.nypost.com/

Gibson, M. 2007, 'Some thoughts on celebrity deaths: Steve Irwin and the issue of public mourning', in Mortality, vol. 12, no. 1, Feb., pp. 1-3.

Gray, F. 2007, 'My daddy was my hero: Steve Irwin, the hero archetype and Australian identity', in A Journal of Archetype and Culture, Psyche \& Nature Part $1 \& 2$, pp. 95-106.

4 Lorraine Code (2000: 322) described masculinity as 'the range of physical, behavioural, and attitudinal qualities that characterize what it means to be a "man" in any given historical or cultural context. 
Greer, G. 2006, 'That sort of self-delusion is what it takes to be a real Aussie larrikin', Guardian, 5 Sept. Retrieved 17 Aug. 2008 from www.guardian.co.uk/

Hamilton, C. 2006, 'Death becomes an excuse to savage 'elites'- Now that's nasty', Sydney Morning Herald, 8 Sept. Retrieved 17 Aug. 2008 from http://www.smh.com.au/

Himes, S. 2006, 'Steve Irwin: 1962-2006', Flak Magazine, 9 Dec. Retrieved 22 Aug. 2008 from http://www.flakmag.com/

Lee, S. 2006, 'Tribute to an Aussie legend', Sunday Territorian, 10 September, p. 15.

Rayner, J. 2007, 'Live and dangerous? The screen life of Steve Irwin', in Studies in Australian Cinema, vol. 1, no. 1, pp. 107-117.

Tumarkin, M. 2007, 'Heroism or just a croc?, The Age Newspaper, 25 August, p. 13.

Turner, G. 2004, Understanding Celebrity, Sage Publications Ltd, London.

Williams, D. 2006, 'Steve Irwin killed by stingray', Sydney Morning Herald, 4 Sept. Retrieved 17 Aug. 2008 from http://www.smh.com.au/ 